\title{
Risk assessment of mouse gastric tissue cancer induced by dichlorvos and dimethoate
}

\author{
QING-LU WANG* ${ }^{*}$ YU-JUN ZHANG ${ }^{*}$, CAI-XIA ZHOU, JIE ZHANG, YE DOU and QIAO-QIAO LI \\ Key Laboratory of Biomedical Engineering and Technology of Shandong High School, \\ Shandong Wanjie Medical College, Zibo 255213, P.R. China
}

Received November 21, 2012; Accepted January 18, 2013

DOI: $10.3892 / \mathrm{ol} .2013 .1155$

\begin{abstract}
Cancer hazards from pesticide residues in food have been much discussed in the past decade. In this study, we showed that dichlorvos and dimethoate affect hemoglobin content and hematocrit value, but had no effect on red blood cell counts and total plasma protein in mice. A $40-\mathrm{mg} / \mathrm{kg} /$ day dose of dichlorvos upregulated the expression of $\mathrm{pl}$, Bcl-2 and $c-m y c$ genes in mouse gastric tissue. By contrast, expression of the $p 16, B c l-2$ and $c-m y c$ genes induced by low doses $(5,10$ and $20 \mathrm{mg} / \mathrm{kg} /$ day) of dichlorvos demonstrated no change in the control check group (CK; $200 \mu 1$ sterile saline perfused group; $0 \mathrm{mg} / \mathrm{kg} /$ day). Different doses of dimethoate all upregulated the expression of $p 16, B c l-2$ and $c$-myc genes in mouse gastric tissue. The results further demonstrated that mouse gastric tissue, exposed in the long-term to low doses of dichlorvos and dimethoate, has the potential to become cancerous.
\end{abstract}

\section{Introduction}

It has been observed that gastric cancer incidence is elevated in farm workers involved in the cultivation of citrus fruits and in workers exposed to high levels of the herbicides 2,4-D and trifluran, the insecticides chlordane and malathion, the fungicides mancozeb and maneb, the fumigant methyl bromide and the acaricide propargite (1). Four of the chemicals associated with elevated gastric cancer incidence (chlordane, maneb, mancozeb and propargite) are class B2 chemicals (probable carcinogens) as classified by the United States Environmental Protection Agency (2006), while trifluran and simazine are class $\mathrm{C}$ chemicals (possible carcinogens).

Correspondence to: Dr Qing-Lu Wang, Key Laboratory of Biomedical Engineering and Technology of Shandong High School, Shandong Wanjie Medical College, 246 Xiwaihuan Road, Zibo 255213, P.R. China

E-mail: wqlzcq@gmail.com

*Contributed equally

Key words: gastric cancer, dichlorvos, dimethoate, transcription, mouse
The gastric cancer subsite distribution was approximately the same between farm workers and Hispanic males in California from 1990-1994. Among the farm workers, 14\% of cancer cases were of the gastric cardia compared with $18.7 \%$ in Californian Hispanic males (2). Similarly, among the farm workers, $61 \%$ of cancer cases were classified as adenocarcinoma, not otherwise specified, and $64 \%$ of Californian Hispanic males were also of this histological type (1).

Dichlorvos has been widely used as an insecticide for $>50$ years. Its carcinogenic potential has been studied extensively and in total there have been 11 long-term studies in rodents; six in rats and five in mice (3). Numerous studies have been carried out on the toxicity of dimethoate in non-target animals and humans. Dimethoate was demonstrated to have an effect on reproductive and endocrine function, enzymatic changes, immunotoxicity, brain acetylcholinesterase activity, proteins and carbohydrate metabolism (4-8).

Few studies have been carried out on the effects of dimethoate in gastric cancer. The present study aimed to investigate the changes in pl6, Bcl-2 and $c-m y c$ gene expression in the gastric tissue of mice following perfusion with the organophosphorous pesticides dichlorvos and dimethoate, which are extensively used in Chinese agricultural areas.

\section{Materials and methods}

Animals and treatment. Male Kunming mice, weighing 180-200 g, were divided randomly into five equal groups, each containing 6 male mice. The mice were purchased from Shandong University (Shandong, China). The mice were routinely screened for common mouse pathogens. The mice used in this study were housed in groups of 6 in stainless steel cages $(50 \times 40 \times 25 \mathrm{~cm})$ in rooms determined to be free of common pathogens under standard conditions $\left(24 \pm 2^{\circ} \mathrm{C}\right.$ and $50 \pm 5 \%$ humidity) with a 12 -h light-dark cycle. The groups were perfused with $0,5,10,20$ or $40 \mathrm{mg} / \mathrm{kg} /$ day dichlorvos suspended in sterile saline $(200 \mu 1,0.9 \% \mathrm{NaCl})$ or $0,2.5,5$, 10 or $20 \mathrm{mg} / \mathrm{kg} /$ day dimethoate suspended in sterile saline $(200 \mu 1,0.9 \% \mathrm{NaCl})$. With the exception of during treatment, the mice had free access to food and water.

After three weeks, all mice were killed by decapitation for the experiments. The esophagus and duodenum were removed and gastric tissue was excised and washed with sterile saline. The tissue was rapidly frozen in liquid nitrogen 
and stored at $-80^{\circ} \mathrm{C}$. All animal procedures were approved by Shandong Wanjie College Animal Investigational Committee and performed in accordance with the Guide for the Care and Use of Laboratory Animals published by Ministry of Health People's Republic of China.

Hematological investigation. Blood samples were collected from the hearts of the mice for hematological investigation. The parameters investigated were the hemoglobin content, hematocrit value (PCV), red blood cell count and total plasma protein (9-11).

Expression analysis of p16, Bcl-2 and c-myc by real-time quantitative ( $q R T)$ - $P C R$. Total RNA was isolated from $<100 \mathrm{mg}$ of tissue by using TRIzol Reagent (Invitrogen Life Technologies, Carlsbad, CA, USA) according to the manufacturer's instructions. Total RNA was quantified by determination of the optical density at $260 \mathrm{~nm}$. First-strand cDNA was produced following instructions for AMV reverse transcriptase (AMV RT) with slight modifications. In the reverse transcription reaction system, $2 \mu \mathrm{g}$ total RNA, $10 \mu \mathrm{l}$ AMV buffer, 75 pmol oligo $\left(\mathrm{dT}_{18}\right)$ and $5 \mu$ l of each of the four deoxynucleotide triphosphates $(10 \mathrm{mM})$ were contained in a total $50 \mu 1$ reaction volume. The mixture was incubated at $95^{\circ} \mathrm{C}$ for 5 min and then 40 units RNase, 10 units AMV RT (Promega, Madison, WI, USA) and $7.5 \mu 125 \mathrm{mM} \mathrm{MgCl}_{2}$ were added. The mixture was incubated at $42^{\circ} \mathrm{C}$ for $60 \mathrm{~min}$ and heated to $95^{\circ} \mathrm{C}$ for $5 \mathrm{~min}$ to inactivate the reverse transcriptase. The cDNA product was stored at $-20^{\circ} \mathrm{C}$.

Oligonucleotides for qRT-PCR (Table I) were designed using Primer Premier 5.0 software (Premier Biosoft International). A BLAST analysis was used against other organism genome sequences for specificity confidence (http:// www.ncbi.nlm.nih.gov/BLAST/). The Mfold web server was applied to avoid positioning on unstable secondary structures. The primer specificity was analyzed before qRT-PCR.

The reaction mixture (final volume, $20 \mu \mathrm{l}$ ) consisted of $10 \mu 1$ SYBR Ex Taq II (Applied Biosystems, Carlsbad, CA, USA), $0.4 \mu 1$ ROX reference dye, $0.8 \mu 1$ of each primer (final concentration, $250 \mathrm{nM}$ ), $7 \mu \mathrm{l} \mathrm{ddH}_{2} \mathrm{O}$ and $1 \mu \mathrm{l}$ cDNA (dilution factor, 1/10). The thermocycling program consisted of two phases; one cycle at $95^{\circ} \mathrm{C}$ for $4 \mathrm{~min}, 40$ cycles at $95^{\circ} \mathrm{C}$ for $15 \mathrm{sec}, 52^{\circ} \mathrm{C}$ for $25 \mathrm{sec}$ and $72^{\circ} \mathrm{C}$ for $35 \mathrm{sec}$. Following completion of these cycles, melting-curve data were collected to verify the PCR specificity, contamination and absence of primer dimers. Each sample was tested in triplicate in a StepOnePlus ${ }^{\mathrm{TM}}$ Real-Time PCR apparatus (Applied Biosystems).

The relative expression levels of $p 16, B c l-2$ and $c-m y c$ were normalized against GAPDH. The normalized relative gene expression levels (indicated as $\mathrm{n}$-fold induction) were evaluated by the Real-Time PCR System Cycler software. The formula was determined as: $\Delta \mathrm{Ct}_{\text {treatment }}$ (the threshold cycle of MT of treated T. thermophila $)=\mathrm{Ct}_{\mathrm{MT} \text { treatment }}-\mathrm{Ct}_{17 \mathrm{~s} \text { treatment }} ; \Delta \mathrm{Ct}_{\text {control }}$ (the threshold cycle of MT of controlled T. thermophila) $=\mathrm{Ct}_{\mathrm{MT}}$ control $-\mathrm{Ct}_{17 \mathrm{~S} \text { control }} ; \Delta \Delta \mathrm{Ct}=\mathrm{Ct}_{\text {treatment }}-\mathrm{Ct}_{\text {control }}$; and the relative quantity levels of MT mRNA expression were $2^{-\mathrm{Ct} \Delta \Delta}$ (12).

Statistical analysis. All hematological results are presented as the mean \pm SD. Data were evaluated using SPSS software
Table I. Real-time quantitative PCR primers.

\begin{tabular}{ll}
\hline Primer & \multicolumn{1}{c}{ Sequence $\left(5^{\prime}-3^{\prime}\right)$} \\
\hline GAPDHF & TGTGTCCGTCGTGGATCTGA \\
GAPDHR & CCTGCTTCACCACCTTCTTGA \\
p16F & GTACCCCGATTCAGGTGATG \\
p16R & TTAGCTCTGCTCTTGGGATTG \\
Bcl-2F & AGGAGCAGGTGCCTACAAGA \\
Bcl-2R & GCATTTTCCCACCACTGTCT \\
c-mycF & GGTGGAAAACCAGGTAAGCA \\
c-mycR & CCTTCTCCTCTGCCATCTTC \\
\hline
\end{tabular}

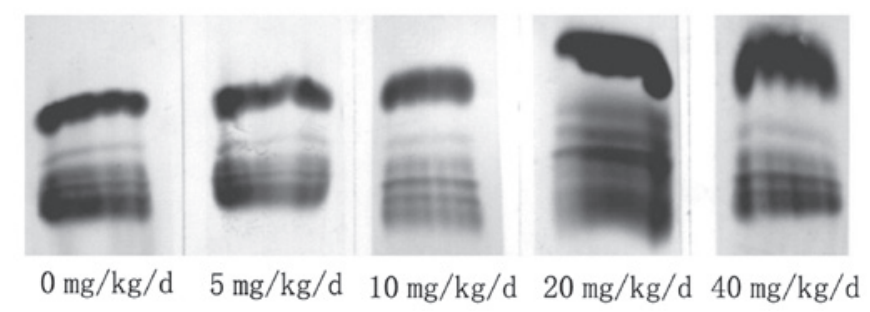

Figure 1. Effects of dichlorvos on the bands of plasma proteins. The electrophoretogram of plasma proteins from mice perfused with $0,5,10,20$ or $40 \mathrm{mg} / \mathrm{kg} /$ day dichlorvos suspended in sterile saline $(200 \mu 1,0.9 \% \mathrm{NaCl})$ for three weeks were analyzed using cellulose acetate membrance electrophoresis. The fractions that appeared clearly were albumin and $\alpha-, \beta$ - and $\gamma$-globulins and these fraction ratios (gray ratio) did not change significantly.
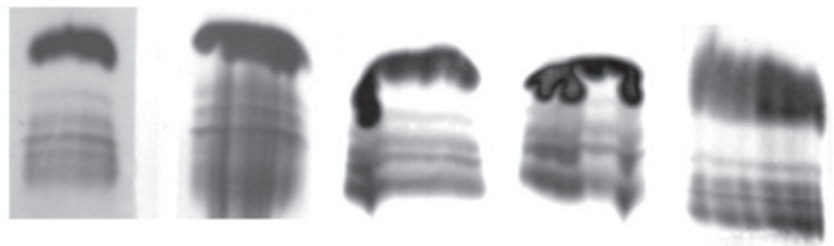

\section{$0 \mathrm{mg} / \mathrm{kg} / \mathrm{d} \quad 2.5 \mathrm{mg} / \mathrm{kg} / \mathrm{d} \quad 5 \mathrm{mg} / \mathrm{kg} / \mathrm{d} \quad 10 \mathrm{mg} / \mathrm{kg} / \mathrm{d} \quad 20 \mathrm{mg} / \mathrm{kg} / \mathrm{d}$}

Figure 2. Effects of dimethoate on the bands of plasma proteins. The electrophoretogram of plasma proteins from mice perfused with $0,0.5,5,10$ or $20 \mathrm{mg} / \mathrm{kg} /$ day dimethoate suspended in sterile saline $(200 \mu 1,0.9 \% \mathrm{NaCl})$ for three weeks were analyzed using cellulose acetate membrance electrophoresis. The fractions that appeared clearly were albumin and $\alpha-, \beta$ - and $\gamma$-globulins and these fraction ratios (gray ratio) did not change significantly.

(SPSS company, USA). Statistical differences were determined using Student's t-test with a significance level set at $\mathrm{P}<0.05$.

\section{Results}

Hematological studies. At the end of the treatment period, no teratogenic mice were observed. The blood parameters investigated were the hemoglobin content, PCV, red blood cell counts and total plasma protein. The results were statistically analyzed using Student's t-test and are shown in Table II.

The hemoglobin content and PCVs showed significant decline in mice treated with $20 \mathrm{mg} / \mathrm{kg}$ /day dichlorvos $(\mathrm{P}<0.05)$ when compared with control values and the decline was also significant in mice treated with $40 \mathrm{mg} / \mathrm{kg} / \mathrm{day}$ dichlorvos $(\mathrm{P}<0.001)$. The plasma protein was investigated quantitatively 
Table II. Hematological studies of mice exposed to dichlorvos.

Dichlorvos dose $(\mathrm{mg} / \mathrm{kg} /$ day $)$

\begin{tabular}{lrccrr}
\cline { 2 - 6 } Parameter & \multicolumn{1}{c}{0} & 5 & 10 & 20 & \multicolumn{2}{c}{40} \\
\hline $\mathrm{Hb}(\mathrm{mg} / 100 \mathrm{ml})$ & $13.33 \pm 1.97$ & $12.83 \pm 2.12$ & $12.15 \pm 2.13$ & $10.95 \pm 1.59^{\mathrm{a}}$ & $9.85 \pm 1.67^{\mathrm{b}}$ \\
$\mathrm{PCV}(\%)$ & $41.0 \pm 2.77$ & $40.35 \pm 3.17$ & $39.86 \pm 4.69$ & $34.9 \pm 3.68^{\mathrm{a}}$ & $32.63 \pm 4.41^{\mathrm{b}}$ \\
Total plasma protein $\left(\mathrm{x} 10^{12} / \mathrm{l}\right)$ & $50.52 \pm 6.22$ & $50.64 \pm 6.20$ & $50.0 \pm 5.98$ & $50.02 \pm 6.08$ & $49.08 \pm 7.21$ \\
RBC count $(\mathrm{mg} / 100 \mathrm{ml})$ & $7.41 \pm 0.32$ & $7.37 \pm 0.40$ & $7.42 \pm 0.22$ & $7.38 \pm 0.96$ & $7.39 \pm 0.26$
\end{tabular}

Results are presented as mean $\pm \mathrm{SD} .{ }^{a} \mathrm{P}<0.05,0 \mathrm{mg} / \mathrm{kg} /$ day dose group vs. $5,10,20$ or $40 \mathrm{mg} / \mathrm{kg} /$ day dose groups. ${ }^{\mathrm{b}} \mathrm{P}<0.001 . \mathrm{Hb}$, hemoglobin; $\mathrm{PCV}$, hematocrit value; RBC, red blood cell.

Table III. Hematological studies of mice exposed to dimethoate.

\begin{tabular}{|c|c|c|c|c|c|}
\hline \multirow[b]{2}{*}{ Parameter } & \multicolumn{5}{|c|}{ Dimethoate dose (mg/kg/day) } \\
\hline & 0 & 2.5 & 5 & 10 & 20 \\
\hline $\mathrm{Hb}(\mathrm{mg} / 100 \mathrm{ml})$ & $13.33 \pm 1.97$ & $12.93 \pm 2.13$ & $11.17 \pm 1.11^{\mathrm{a}}$ & $9.55 \pm 1.59^{\mathrm{a}}$ & $8.05 \pm 1.67^{\mathrm{b}}$ \\
\hline $\mathrm{PCV}(\%)$ & $41.0 \pm 2.77$ & $40.45 \pm 3.14$ & $37.86 \pm 1.08^{\mathrm{a}}$ & $36.4 \pm 1.68^{\mathrm{a}}$ & $33.67 \pm 0.71^{\mathrm{b}}$ \\
\hline \multicolumn{2}{|c|}{ Total plasma protein $(\mathrm{mg} / 100 \mathrm{ml}) 50.52 \pm 6.22$} & $50.65 \pm 6.01$ & $50.32 \pm 5.78$ & $49.02 \pm 6.38$ & $49.08 \pm 7.67$ \\
\hline $\mathrm{RBC}$ count $\left(\mathrm{x} 10^{12} / 1\right)$ & $7.41 \pm 0.32$ & $7.40 \pm 0.29$ & $7.38 \pm 0.82$ & $7.39 \pm 0.86$ & $7.37 \pm 0.76$ \\
\hline
\end{tabular}

Results are presented as mean $\pm \mathrm{SD} .{ }^{\mathrm{a}} \mathrm{P}<0.05,0 \mathrm{mg} / \mathrm{kg} /$ day dose group vs. $2.5,5,10$ or $20 \mathrm{mg} / \mathrm{kg} /$ day dose groups. ${ }^{\mathrm{b}} \mathrm{P}<0.001 . \mathrm{Hb}$, hemoglobin; PCV, hematocrit value; RBC, red blood cell.
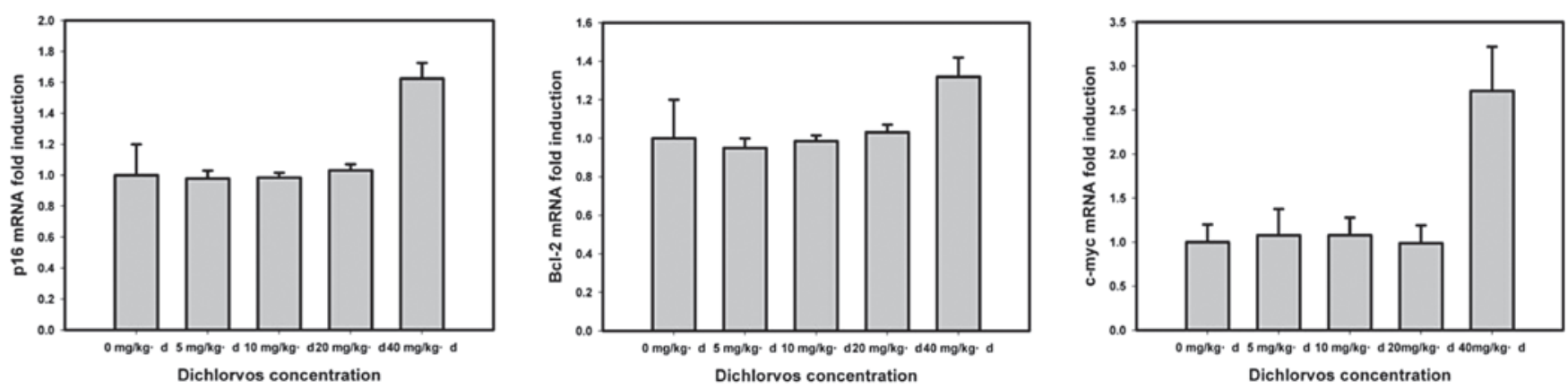

Figure 3. Effects of dichlorvos on the expression levels of the $p 16, B c l-2$ and $c-m y c$ genes. Relative expression levels of the $p 16, B c l-2$ and $c-m y c$ genes were obtained by real-time quantitative PCR. Fold-induction was determined for the $p 16, B c l-2$ and $c$ - $m y c$ genes after mice were perfused with $0,5,10,20$ or $40 \mathrm{mg} / \mathrm{kg} /$ day dichlorvos suspended in sterile saline $(200 \mu \mathrm{l}, 0.9 \% \mathrm{NaCl})$ for three weeks. Gene expression levels are shown in comparison with an untreated control.
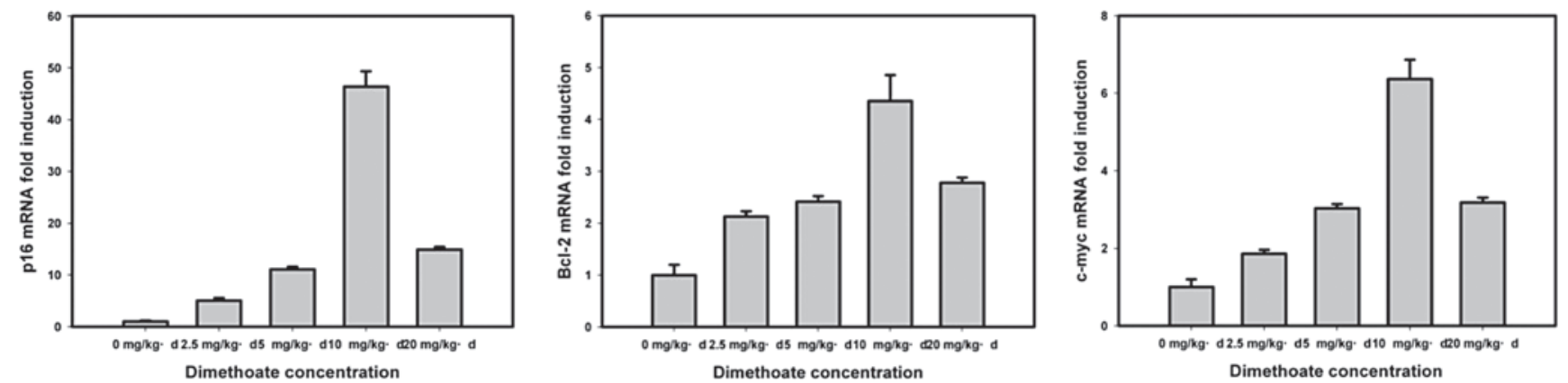

Figure 4. Effects of dimethoate on the expression levels of the $p 16, B c l-2$ and $c$-myc genes. Relative expression levels of the $p 16, B c l-2$ and $c$-myc gene were obtained by real-time quantitative PCR. Fold-induction was determined for the $p 16, B c l-2$ and $c$ - $m y c$ genes after mice were perfused with $0,2.5,5,10$ or $20 \mathrm{mg} / \mathrm{kg} /$ day dimethoate suspended in sterile saline $(200 \mu 1,0.9 \% \mathrm{NaCl})$ for three weeks. Gene expression levels are shown in comparison with an untreated control. 
and qualitatively. The total plasma protein content was not significantly different between the mice treated with different doses of dichlorvos and those from the control group. The electrophoretic investigation showed no significant differences between the differential bands of plasma proteins in the treated and control mice (Fig. 1). The fractions that appeared clearly were albumin and $\alpha$-, $\beta$ - and $\gamma$-globulins. The red blood cell counts from control and treated mice are shown in Table III. The red blood cell counts in mice treated with each of the dichlorvos concentrations were not significantly different from those of the controls $(\mathrm{P}>0.05)$.

Compared with the control mice, mice treated with 5, 10 or $20 \mathrm{mg} / \mathrm{kg} /$ day dimethoate showed a change in their hemoglobin content and PCVs. There was a significant decline in the $5 \mathrm{mg} / \mathrm{kg} /$ day group, followed by the $10 \mathrm{mg} / \mathrm{kg} /$ day group and in the $20 \mathrm{mg} / \mathrm{kg} /$ day group, the decline was the most evident (Table III). The albumin and $\alpha$-, $\beta$ - and $\gamma$-globulins appeared clearly in the electrophoretic fractions for the total plasma protein and their concentration ratios did not change significantly (Fig. 2). The red blood cell counts in mice treated with each of the dimethoate concentrations were not significantly different from those of the controls $(\mathrm{P}>0.05)$.

Effects of dichlorvos on expression of the p16, Bcl-2 and $c$-myc genes. Comparative gene expression analysis of the p16, Bcl-2 and $c$-myc genes was carried out under various concentration stress conditions using qRT-PCR. Results show mRNA expression levels of the p16, Bcl-2 and $c$-myc genes induced by various concentration stressors, normalized against the level of GAPDH (the reference gene). In dichlorvos induction, the $p 16, B c l-2$ and $c$-myc expression levels showed no clear change with low dichlorvos concentrations ( $<20 \mathrm{mg} / \mathrm{kg} /$ day), however, levels subsequently increased with 20- to $40-\mathrm{mg} / \mathrm{kg} /$ day dichlorvos concentrations. Fig. 3 shows that the effect of dichlorvos on $\mathrm{Bcl}-2$ (1.3-fold) was the lowest compared with the upregulated expression fold, the next was pl6 (1.7-fold) and $c-m y c$ (2.8-fold) demonstrated the greatest effects.

Effects of dimethoate on expression of the p16, Bcl-2 and $c$-myc genes. Expression of the p16, Bcl-2 and $c$-myc gene transcripts was assessed after in vivo exposure to dimethoate. The concentrations used were $<1 / 2$ the LC50 value of the mouse. In dimethoate induction, the $\mathrm{p} 16, \mathrm{Bcl}-2$ and $c-m y c$ expression levels gradually increased with concentrations $<10 \mathrm{mg} / \mathrm{kg} / \mathrm{day}$ and subsequently decreased with $10-$ and $20-\mathrm{mg} / \mathrm{kg} /$ day dimethoate concentrations (Fig. 4). The effect of dimethoate on the expression of $\mathrm{Bcl}-2$ (4.5-fold) was the lowest, the next was $c$-myc (6.1-fold) and p16 (48-fold) demonstrated the greatest effects.

\section{Discussion}

In the past decade, the incidence of gastric cancer has been declining, however it remains the fourth most common cancer and the second most frequent cause of cancer-associated mortalities $(13,14)$. The reason for the decline in gastric cancer incidence is possibly due to the recognition of specific risk factors, including $H$. pylori, and dietary and environmental risks. However, gastric cancer is the predominant type of cancer in farmers in the developing world, particularly China, and remains a significant cancer burden (15).

In this study, the risks to mouse gastric tissue were analyzed by continuous exposure to low doses of dichlorvos and dimethoate. We showed that red blood cell counts and total plasma protein in these mice were not affected by dichlorvos and dimethoate, while hemoglobin content and PCVs demonstrated a significant decline in treated mice when exposed to higher doses of dichlorvos (20-40 mg/kg/day) and dimethoate $(5-20 \mathrm{mg} / \mathrm{kg} /$ day). These results suggest that the pesticides in this study were able to affect the physiological functions of mice, however, the impacts were small.

A number of biological markers, including oncogenes, tumor suppressor genes, cell cycle regulators and DNA repair genes, were correlated with the genesis, growth, invasion and metastasis of tumors and they may be used as prognostic factors for tumors (16). Currently, numerous studies have evaluated the prognostic significance of markers, such as the p16, Bcl-2, MTDH and $c-m y c$ genes in gastric cancer (17-19). This study also evaluated expression of the $p 16, B c l-2$ and $c-m y c$ genes. Results showed that expression of the $p 16, B c l-2$ and $c-m y c$ genes in mouse gastric tissue was not affected when it was exposed to low concentrations of dichlorvos (5, 10 or $20 \mathrm{mg} / \mathrm{kg} /$ day), however, there was a significant increase in expression levels with a $40-\mathrm{mg} / \mathrm{kg} /$ day dose of dichlorvos. These results suggest the risk of tumorigenesis caused by dichlorvos was substantial, but not high, when mice were continuously exposed to dichlorvos. The risk of tumorigenesis induced by dimethoate was higher than for dichlorvos. Low doses of dimethoate were able to induce expression of the p16, Bcl-2 and $c$-myc genes in mouse gastric tissue. There was a positive correlation between dimethoate concentration and expression levels of the $\mathrm{pl6}, \mathrm{Bcl}-2$ and $c$-myc genes. In the $20 \mathrm{mg} / \mathrm{kg} /$ day group, the cause of the apparent decline in expression levels of these genes may be due to the function of cells being affected.

In conclusion, cancer hazards from pesticide residues in food have been much discussed in decades past. Our results suggest that mouse gastric tissue exposed long-term to low dose dichlorvos and dimethoate has the potential to become cancerous. However, the mechanisms of gastric tissue cancerization induced by pesticide remains to be elucidated by further studies in the future.

\section{References}

1. Mills PK and Yang RC: Agricultural exposures and gastric cancer risk in Hispanic farm workers in California. Environ Res 104: 282-289, 2007.

2. Perkins CI, Cohen R, Young JL, Schlag R and Wright WE: Cancer in California: Detailed Site and Histology, 1990-1994. Sacramento: California Cancer Registry, 1997.

3. Ishmael J, MacGregor JA and Manley A: Dichlorvos - a comprehensive review of 11 rodent carcinogenicity studies. Regul Toxicol Pharmacol 44: 238-248, 2006.

4. Rawlings NC, Cook SJ and Waldbillig D: Effects of the pesticides carbofuran, chlorpyrifos, dimethoate, lindane, triallate, trifluralin, 2,4-D, and pentachlorophenol on the metabolic endocrine and reproductive endocrine system in ewes. J Toxicol Environ Health A 54: 21-36, 1998.

5. Begum G and Vijayaraghavan S: Alterations in protein metabolism of muscle tissue in the fish Clarias batrachus (Linn) by commercial grade dimethoate. Bull Environ Contam Toxicol 57: 223-228, 1996. 
6. Institóris L, Siroki O and Dési I: Immunotoxicity study of repeated small doses of dimethoate and methylparathion administered to rats over three generations. Hum Exp Toxicol 14 879-883, 1995

7. Dell'Omo G and Shore RF: Behavioral effects of acute sublethal exposure to dimethoate on wood mice, Apodemus sylvaticus: II Field studies on radio-tagged mice in a cereal ecosystem. Arch Environ Contam Toxicol 31: 538-542, 1996.

8. Begum $\mathrm{G}$ and Vijayaraghavan S: In vivo toxicity of dimethoate on proteins and transaminases in the liver tissue of fresh water fish Clarias batrachus (Linn). Bull Environ Contam Toxicol 54: 370-375, 1995.

9. Silva MA, Ronconi A, Cordeiro N, et al: Blood parasites, total plasma protein and packed cell volume of small wild mammals trapped in three mountain ranges of the Atlantic Forest in Southeastern Brazil. Braz J Biol 67: 531-535, 2007.

10. Spiess BD, Ley C, Body SC, et al: Hematocrit value on intensive care unit entry influences the frequency of Q-wave myocardial infarction after coronary artery bypass grafting. The Institutions of the Multicenter Study of Perioperative Ischemia (McSPI) Research Group. J Thorac Cardiovasc Surg 116: 460-467, 1998.

11. Tilak KS, Veeraiah K and Raju JM: Effects of ammonia, nitrite and nitrate on hemoglobin content and oxygen consumption of freshwater fish, Cyprinus carpio (Linnaeus). J Environ Biol 28: 45-47, 2007.
12. Applied Biosystems: User Bulletin No. 2. ABI Prism 7700 Sequence Detection System, 1997.

13. Shibata A and Parsonnet J: Stomach cancer. In: Cancer Epidemiology and Prevention. Schottenfeld D and Fraumeni JF (eds). 3rd edition. Oxford University Press, New York, pp707-720, 2006.

14. Parkin DM, Bray F, Ferlay J and Pisani P: Global cancer statistics, 2002. CA Cancer J Clin 55: 74-108, 2005.

15. Shi J, Zhang G, Yao D, et al: Prognostic significance of aberrant gene methylation in gastric cancer. Am J Cancer Res 2: 116-129, 2012.

16. Bashir SA, Pandith AA, Yousuf A, et al: Lack of p16 gene mutations in gastric cancers in Kashmir. Asian Pac J Cancer Prev 11: 339-342, 2010

17. Liu X, Cai H, Huang H, Long Z, Shi Y and Wang Y: The prognostic significance of apoptosis-related biological markers in Chinese gastric cancer patients. PLoS One 6: e29670, 2011.

18. Wang P, Mei J, Zhang N, Tao J, Tian H and Fu GH: Helicobacter pylori upregulates the expression of p16(INK4) in gastric cancer cells. Hepatogastroenterology 58: 846-853, 2011.

19. Mitomi H, Fukui N, Kishimoto I, et al: Role for p16(INK4a) in progression of gastrointestinal stromal tumors of the stomach: alteration of p16(INK4a) network members. Hum Pathol 42: 1505-1513, 2011. 